International Journal of Medical Sciences

ISSN 1449-1907 www.medsci.org 2005 2(2):64-69

(C)2005 Ivyspring International Publisher. All rights reserved

\title{
Research paper $\quad$ Cell Cycle Arrest by a Natural Product via G2/M Checkpoint
}

Received: 2004.09.01

Accepted: 2005.02.01

Published: 2005.04.01
Sharon Chui-Wah Luk, Stephanie Wing-Fai Siu, Chun-Kit Lai, Ying-Jye Wu, Shiu-Fun Pang

Technology Development, CK Life Sciences Int'l Inc., 2 Dai Fu Street, Tai Po Industrial Estate, Hong Kong, China

Abstract $\mathrm{CKBM}$ is a natural product that exhibits a novel anti-tumor activity through the induction of cell cycle arrest and apoptosis. We have investigated its effects on cell cycle regulation using a gastric cancer cell line, AGS. The effects of CKBM on cell proliferation, cell cycle regulation and apoptosis were analyzed using BrdU (5-bromo-2'-deoxyuridine) cell proliferation assay and flow cytometric analysis, respectively. Specific cellular protein expressions were measured using Western blot analysis. Flow cytometric analysis indicated that CKBM induced $\mathrm{G} 2 / \mathrm{M}$ cell cycle arrest and apoptosis, whereas differential protein expressions of

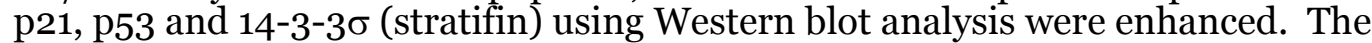
differential expressions of p21, p53 and 14-3-3 $\sigma$ in AGS cancer cells after CKBM treatment may play critical roles in the G2/M cell cycle arrest that blocks cell proliferation and induces apoptosis.

Key words

Author biography

Corresponding address
14-3-3 $\sigma$ (stratifin), G2/M arrest, cell proliferation, checkpoint protein

Sharon Chui-Wah Luk (Ph.D.) is Project Manager of CK Life Sciences Int'l Inc. She graduated from University of Alberta with a bachelor degree before completing Ph.D. study in the Department of Biochemistry, The Chinese University of Hong Kong. Her research interest is in cancer therapy.

Stephanie Wing-Fai Siu (M. Phil.) is Science Officer of CK Life Sciences Int'l Inc. She graduated from University of Hong Kong in the Department of Physiology. Her current research is in anti-cancer research.

Chun-Kit Lai (B.Sc.) is Science Assistant of CK Life Sciences Int'l Inc. He graduated from The Chinese University of Hong Kong in the Department of Biology. His current research is in proteomics.

Ying-Jye Wu (Ph.D.) has over 20 years of experience with US biomedical industry and is knowledgeable in the development of FDA-approved cancer, AIDS and hepatitis B products including proteomics-based diagnostic products for early cancer detection.

Shiu-Fun Pang (Ph.D.) is Vice President and Chief Technology Officer of CK Life Sciences Int'l Inc. Dr. Pang was the Head of Department of Physiology at University of Hong Kong prior joining the company. He had been the founding Editor and Editor-in-Chief of Biological Signals and Biological Signals and Receptors, Adjunct Professor of University of Toronto and is Honorary or Visiting Professor of over ten universities.

S.C.W. Luk, 2 Dai Fu Street, Tai Po Industrial Estate, Hong Kong, China. Tel: (852) 2126-1641 Fax: (852) 2126-1211 E-mail: sharon.luk@ck-lifesciences.com 


\section{Introduction}

Pharmaceutical research of traditional Chinese medicines on cancer prevention and treatment has attracted much attention. There are a number of herbs that have shown to have the abilities to induce cell cycle arrest and to play an important role in cancer prevention. Genistein, daidzein and isoflavonoids in soybean are thought to play an important role in breast cancer prevention [1]. In addition, genistein is found to induce G2/M cell cycle arrest in MCF-7 cells [2]. Whereas anti-carcinogenic compounds like lunasin and lectins in soybean were shown to induce apoptosis in malignant cells [3]. Schisandra chinensis is shown to reduce prostate cancer cell growth and induce apoptosis by inhibiting androgen receptor expression [4]. Panax ginseng and Ziziphus jujube are found to induce cytokine release in macrophages [5]. Moreover, soluble $\beta$-glucans from Saccharomyces cerevisiae could activate macrophage to secrete TNF- $\alpha$ [6], which is found to have a pro-apoptotic effect on human cancer cells [7].

CKBM is a product that contains the water extracts of wu wei zi (Schisandra chinensis), ginseng (Panax ginseng), hawthorn (Fructus Crataegi), jujube (Ziziphus jujube), soybean (Glycine Max) and Baker's yeast (Saccharomyces cerevisiae) which is processed by a proprietary technology developed by CK Life Sciences Int'l Inc., Hong Kong, China (CKLS). CKBM had previously been found to significantly enhance the secretion of IL-6, IL-8 and TNF- $\alpha$ in human peripheral blood mononuclear cells [8]. In addition, it can increase the activities of natural killer cells and the phagocytic index of macrophage [9]. The anti-tumor effect of CKBM was demonstrated in nude mice xenograft model with gastric cancer cells [10], in which CKBM showed a dosedependent inhibition of tumor growth with significant tumor volume reduction in the treatment group. In the present study, tumor suppressive and pro-apoptotic effect of CKBM is further investigated in AGS, a gastric cancer cell line. CKBM is found to inhibit cell proliferation through the induction of apoptosis and G2/M cell cycle arrest. To further elucidate the mechanism of CKBM on apoptosis and G2/M cell cycle arrest, we studied the cellular protein expression profile of human gastric cancer cell line (AGS) before and after CKBM treatment using Western blot analysis.

\section{Materials and Methods}

\section{Cell culture}

Human gastric cancer cell line (AGS) was obtained from American Type Culture Collection (Rockville, MD, USA). Cells were cultured in F12K medium (Invitrogen Life Technologies, Inc., CA, USA) supplemented with $10 \% \mathrm{v} / \mathrm{v}$ fetal bovine serum (FBS) and $1 \%$ Penicillin/Streptomycin (Invitrogen Life Technologies, Inc., CA, USA) at $5 \% \mathrm{CO}_{2}, 37{ }^{\circ} \mathrm{C}$.

\section{Cell proliferation assay (BrdU)}

Cells were seeded in a 96-well flat bottom plate at a density of $1 \times 10^{4}$ cells/well. After $24 \mathrm{hr}, 20 \mu \mathrm{l}$ of CKBM (Batch no. 0212191 ) at a final concentration of $2,4,6,8,10,12,14,16$ or $18 \% \mathrm{v} / \mathrm{v}$ was added and incubated for either 24 or $48 \mathrm{hr}$ at $5 \% \mathrm{CO}_{2}$, $37^{\circ} \mathrm{C}$. Cell proliferation was assayed using BrdU (5-bromo-2'-deoxyuridine) kit purchased from Amersham (Uppsala, Sweden) and it was performed according to the kit manual.

\section{Analysis of cell cycle progression}

Cells were seeded in a $25 \mathrm{~cm}^{2}$ flask at a density of $1 \times 10^{6}$ cells/flask. After $24 \mathrm{hr}$, at a final concentration of $0,5 \mathrm{or} 10 \% \mathrm{v} / \mathrm{v}$ of CKBM was added to the respective flask and incubated for 24, 48 or $72 \mathrm{hr}$. Cells were trypsinized, harvested, and fixed in $1 \mathrm{ml}$ $80 \%$ cold ethanol in test tubes and incubated at $4{ }^{\circ} \mathrm{C}$ for $15 \mathrm{~min}$. After incubation, cells were centrifuged at 1,500 rpm for $5 \mathrm{~min}$ and the cell pellets were resuspended in $500 \mu \mathrm{l}$ propidium iodine $(10 \mu \mathrm{g} / \mathrm{ml})$ containing $300 \mu \mathrm{g} / \mathrm{ml} \mathrm{RNase}$ (Sigma, MO, USA). Then cells were incubated on ice for $30 \mathrm{~min}$ and filtered with $53 \mu \mathrm{m}$ nylon mesh. Cell cycle distribution was calculated from 10,000 cells with ModFit LT ${ }^{\mathrm{TM}}$ software (Becton Dickinson, CA, USA) using FACScaliber (Becton Dickinson, CA, USA).

\section{Apoptotic analysis with Annexin V Staining}

AGS cells were seeded in a 6-well plate at a density of $1.2 \times 10^{6}$ cells/well. After 2,4 or $6 \mathrm{hr}$ of CKBM treatment at a concentration of 5,10 or $15 \% \mathrm{v} / \mathrm{v}$, cells were trypsinized. Then cells were washed twice with cold PBS and $1 \times 10^{6}$ cells were resuspended in $500 \mathrm{ml} 1 \mathrm{X}$ binding buffer. A hundred microliter of cell suspension was transferred to a $5 \mathrm{ml}$ culture tube and incubated with $10 \mu \mathrm{l}$ of Annexin V antibodies and $10 \mu \mathrm{l}$ of propidium iodine $(10 \mu \mathrm{g} / \mathrm{ml})$ containing $300 \mu \mathrm{g} / \mathrm{ml} \mathrm{RNase}$ (Sigma, MO, USA). Gently vortex the cells and incubate for $15 \mathrm{~min}$ at RT in the dark. Four hundred microliter of $1 \mathrm{X}$ binding buffer was added to each tube and the cells were analyzed with flow cytometry within $1 \mathrm{hr}$.

\section{Western blot analysis}

Cells were seeded in a $150 \mathrm{~mm}$ Petri dish at a density of $1 \times 10^{5}$ cells $/ \mathrm{ml}$. After $24 \mathrm{hr}$, a final concentration of $0,0.25,0.5,1$, $2.5,5$ or $10 \% \mathrm{v} / \mathrm{v}$ of CKBM was added and incubated for $48 \mathrm{hr}$. The cells were then trypsinized and washed twice with PBS and lysed with lysis buffer $(50 \mathrm{mM}$ Tris-HCl, $\mathrm{pH} 7.5,250 \mathrm{mM} \mathrm{NaCl}, 5 \mathrm{mM}$ EDTA, pH 8.0, 0.2 \% Triton X-100 and add $10 \mu \mathrm{l}$ protease inhibitor cocktail per $1 \mathrm{ml}$ cell lysate at a cell density of $10^{8}$ cells $\left./ \mathrm{ml}\right)$ at $4{ }^{\circ} \mathrm{C}$. Lysates in sample buffer $(2 \%$ SDS, $10 \%$ glycerol, 80 $\mathrm{mM}$ Tris- $\mathrm{HCl}(\mathrm{pH} 6.8), 720 \mathrm{mM}$ 2-mercaptoethanol and $0.001 \%$ bromophenol blue) were denatured at $95{ }^{\circ} \mathrm{C}$ for 5 min. Total cellular proteins $(20-100 \mu \mathrm{g})$ were subjected to SDS-polyacrylamide gel electrophoresis (PAGE) and the proteins were transferred to Hybond-P PVDF membrane (Amersham, Buckinghamshire, England). The membranes were blocked with $5 \%$ non-fat dried milk in $1 \mathrm{X} \mathrm{PBS} / 1 \%$ Tween 20 at $4{ }^{\circ} \mathrm{C}$ overnight and incubated with primary antibodies (anti-p21, anti-14-3-3 $\sigma$ and anti-p53 at 1:5000 in TBST; anti-actin at 1:10000 in TBST) (Santa Cruz Biotechnology Inc., CA, USA) at room temperature for 2 hours followed by incubation of horseradish peroxidase-conjugated rabbit anti-mouse IgG (1:25000 in TBST) (Santa Cruz Biotechnology Inc., CA, USA) at room temperature for 2 hours. Reactive protein bands were visualized using ECL Plus Western blotting detection reagents (Amersham, Uppsala, Sweden) and the bands intensities were scanned and quantified using a densitometer.

\section{Results}

We examined the effect of CKBM on the proliferation of AGS using BrdU cell proliferation assay. The dosage of CKBM ranged from 2 to $18 \%$. CKBM inhibited cell proliferation in a dose-dependent manner (Fig. 1), the higher the CKBM dosage, the higher the degree of inhibition. The $\mathrm{IC}_{50}$ value for AGS was found to be approximately $6 \%$ and proliferation was suppressed at 10 
$\%$ or higher (Fig. 1). AGS cells underwent morphological changes from a polygonal appearance to an elongated shape after CKBM treatment (5 and $10 \%)$ (Fig. 2).

The effect of CKBM on cell cycle was evaluated using flow cytometric analysis. We observed a dose-dependent but timeindependent effect of CKBM on the cell cycle. After $72 \mathrm{hr}$ of $5 \%$ CKBM treatment, cells in the G2/M population increased from $11.6 \%$ to $20.6 \%$ compared to control whereas cells with $15 \%$ CKBM treatment, the G2/M population increased to $50.5 \%$ The increase of cell population at the G2/M phase was accompanied by a decrease of cell population in the G1 phase of the cell cycle (Fig. 3). The effect of CKBM on AGS cells appears to be dose-dependent, the higher the dosage the greater the G2/M population increases. This dose-dependent effect was also demonstrated at the three dosages that we had examined however the length of CKBM treatment did not further contribute to the G2/M population increase (Fig. 3).

Apoptotic effect of CKBM was evaluated with Annexin V staining and a dose-dependent relationship was found (Fig. 4). After $2 \mathrm{hr}$ of $0,5,10$ or $15 \%$ CKBM incubation, the apoptotic population increased from $2.8 \%$ in the control group compared to $16.5 \%$ in the $15 \%$ treatment group. The dose-dependent effect was also observed in the 4 and $6 \mathrm{hr}$ CKBM treatment groups, however, the apoptotic population decreased with $15 \%$ treatment because the cells in the late stage of apoptosis were indistinguishable from the necrotic population. The increase in the apoptotic population is in concomitant with the increase in the pre-phase population that was observed in the cell cycle analysis (Fig. 3).

In CKBM treated AGS cancer cells, p21, p53 and 14-3-3 $\sigma$ all showed an increase in protein expressions in a dose-dependent

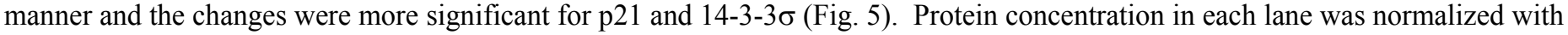

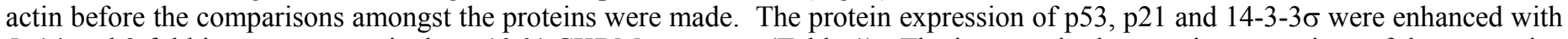
5,14 and 3 fold increase respectively at $10 \%$ CKBM treatment (Table 1). The increase in the protein expressions of these proteins correlated well with the BrdU cell proliferation assay, in which we found the cell proliferation of AGS cancer cells decreased.

Table 1. The Ratio of p53, p21 and 14-3-3s protein expression between the control and the CKBM-treated AGS cells after actin normalization.

\section{Disscussion}

Cell cycle checkpoints are important control mechanisms that ensure the proper execution of cell cycle

\begin{tabular}{|c|c|c|c|c|c|c|}
\hline Protein $\backslash[\mathbf{C K B M}] \%$ & $\mathbf{0 . 2 5}$ & $\mathbf{0 . 5}$ & $\mathbf{1}$ & $\mathbf{2 . 5}$ & $\mathbf{5}$ & $\mathbf{1 0}$ \\
\hline $\mathbf{p 5 3}$ & 2.7 & 2.9 & 4.0 & 4.7 & 5.0 & 5.0 \\
\hline $\mathbf{p 2 1}$ & 0.8 & 2.5 & 3.0 & 3.4 & 5.0 & 14.3 \\
\hline $\mathbf{1 4 - 3 - 3}$ & 1.0 & 1.5 & 1.2 & 2.0 & 2.4 & 3.3 \\
\hline
\end{tabular}
events. One of the checkpoints, the G2/M checkpoint blocks the entry into mitosis when DNA is damaged [11]. p53 can regulate

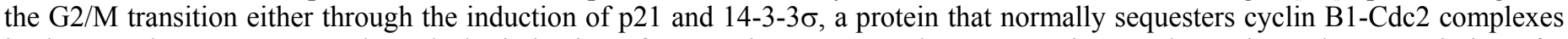
in the cytoplasm $[12,13]$ or through the induction of apoptosis $[14,15]$. The p53 protein can also activate the transcription of a variety of apoptosis-associated genes, and to program cell death in response to genotoxic stresses [16, 17]. 14-3-3 $\sigma$ (stratifin), p21, and Gadd45 are three major transcriptional targets of p53 that can simultaneously inhibit Cdc2, which is essential for the entry into mitosis $[11,18]$.

In this study, we demonstrated that CKBM is able to inhibit cell proliferation in human gastric cancer cell line, AGS. The data from a subcutaneous implantation model of gastric cancer tissue was also agreeable to our observation in which anti-tumor effect was demonstrated showing a significant decrease in tumor volume [10]. The mechanism for the inhibition was further investigated with cell cycle analysis, apoptotic study and Western blot analysis. The results showed that CKBM is able to induce a G2/M cell cycle arrest and a dose-dependent apoptotic effect in AGS cells. Using Western blot analysis, it was revealed that the expressions of p21, p53 and 14-3-3 $\sigma$ proteins in AGS are enhanced after CKBM treatment. It is well known that these three proteins play an important role in cell cycle regulation. p21 is an inhibitor of cyclin/cyclin-dependent kinase complexes, and it interacts with other regulators of signal transduction [19]. Its induction is mediated by both p53 and p53-independent mechanisms and is essential for the onset of both G1 and G2 cell cycle arrest in damage response and cell senescence [19]. The 14-3-3 proteins belong to a family of highly conserved proteins (alpha, beta, delta, sigma, tau, zeta etc.) with molecular weight of 25- to 30-kDa. They are expressed in all eukaryotic cells and modulate a wide variety of cellular processes [20]. They play a critical role in the regulation of signal transduction pathways associated with the control of cell proliferation, differentiation, and survival [21]. This family of proteins is known to interact directly or indirectly with signaling proteins such as the insulin-like growth factor I receptor, Raf, MEK kinases, PI3-kinase. However, the exact mechanism by which they activate or inhibit these elements remains unclear [21]. It had been shown that $14-3-3 \sigma$ is a p53-dependent inhibitor of G2/M progression, and that its over-expression can cause G2/M cell cycle arrest [11]. Furthermore, it is able to up-regulate Cdc2 phosphorylation via Wee1 and down-regulate Cdc25c thus controlling the entry of cells into mitosis by maintaining the G2/M checkpoint [22]. Other researchers had also found that over-expression of 14-3-3 $\sigma$ in breast cancer cell lines was able to inhibit cell proliferation and prevent anchorage-independent growth [23]. These results have led them to speculate that 14-3-3 $\sigma$ might be a potential candidate as tumor suppressor [23]. In addition, previously study showed that proteolysis of $14-3-3 \sigma$ by Efp promotes breast tumor growth and suggested that 14-3-3 $\sigma$ protein might play an important role in regulating tumor growth [24].

\section{Conclusion}

In this study, we demonstrated that CKBM inhibits cell proliferation through the induction of G2/M cell cycle arrest and dosedependent apoptotic effect. From the results, we speculate that the induction of G2/M arrest and apoptosis may be partly due to the increase of the p21, p53 and 14-3-3 $\sigma$ protein expressions evidenced by the Western blot analysis. Whether other proteins are also involved in the induction of $\mathrm{G} 2 / \mathrm{M}$ cell cycle arrest and inhibition in cell proliferation still need further studies. In summary, we have used flow cytometry and Western blot analysis to examine the effect of CKBM on AGS cell cycle regulation. The results indicate that the increase in p21, p53, and 14-3-3 $\sigma$ after treatment of CKBM may contribute to the G2/M cell cycle arrest and the induction of apoptosis in human AGS cancer cell line. 


\section{Conflict of interest} Int'l Inc.

Sharon Chui-Wah Luk, Stephanie Wing-Fai Siu, Chun-Kit Lai, Ying-Jye Wu, and Shiu-Fun Pang work for CK Life Sciences

\section{References}

1. Wang HZ, Zhang Y, Xie LP, Yu XY, Zhang RQ. Effects of genistein and daidzein on the cell growth, cell cycle, and differentiation of human and murine melanoma cells. J Nutr Biochem 2002; 13:421-426.

2. Chen WF, Huang MH, Tzang CH, Yang M, Wong MS. Inhibitory actions of genistein in human breast cancer (MCF-7) cells. Biochim Biophys Acta 2003; 1638:187-196.

3. de Mejia EG, Bradford T, Hasler C. The anticarcinogenic potential of soybean lectin and lunasin. Nutr Rev 2003; 61:239-246.

4. Hsieh TC, Lu X, Guo J, Xiong W, Kunicki J, Darzynkiewicz Z, Wu JM. Effects of herbal preparation Equiguard on hormone-responsive and hormone-refractory prostate carcinoma cells: mechanistic studies. Int J Oncol 2002; 20:681-689.

5. Shin YJ, Song JY, Yun YS, Yang HO, Rhee DK, Pyo S. Immunostimulating effects of acidic polysaccharides extract of Panax ginseng on macrophage function. Immunopharmacol Immunotoxicol 2002; 24:469-482.

6. Lee DY, Ji IH, Chang HI, Kim CW. High-level TNF- $\alpha$ secretion and macrophage activity with soluble $\beta$-glucans from Saccharomyces cerevisiae. BioSci Biotechnol Biochem 2002; 66:233-238.

7. Gillio Tos A, Cignetti A, Rovera G, Foa R. Retroviral vector-mediated transfer of the tumour necrosis factor alpha gene into human cancer cells restores an apoptotic cell death program and induces a bystander-killing effect. Blood 1996; 87:2486-2495.

8. Chan BP, Yuen WF, Lee WH, Wong SN, Chung TY, Wu YJ, Pang SF. Immunomodulating effects of CKBM-T01 on the cytokine production in peripheral blood mononuclear cells (PBMCs) from healthy volunteers. Immunopharmacol Immunotoxicol 2004; 26:177-192.

9. Pang JJ, Shan HM, Xu RK, Luk CW, Pang SF, Xu JN. Chang Ke Zhi Ji Zeng Qiang Shi Yan Dong Wu De Mian Yi Gong Leng. World Clinical Drugs 2004; 25(7):444-448.

10. Shin VY, So WHL, Liu ESL, Wu YJ, Pang SF, Cho CH. Anti-tumorigenic and Pro-apoptotic effects of CKBM-T01 on gastric cancer growth in nude mice. Int J Med Sci 2004; 1(3):137-145.

11. Taylor WR, Stark G.R. Regulation of the G2/M transition by p53. Oncogene 2001; 20:1803-1815.

12. Hermeking H, Lengauer C, Polyak K, He T-C, Zhang L, Thiagalingam S, Kinzler KW, Vogelstein B. 14-3-3 sigma is a p53-regulated inhibitor of G2/M progression. Mol Cell 1997; 1:3-11.

13. Bunz F, Dutriaux A, Lengauer C, Waldman T, Zhou S, Brown JP, Sedivy JM, Kinzler KW, Vogelstein B. Requirement for p53 and p21 to sustain G2 arrest after DNA damage. Science 1998; 282:1497-1501.

14. Yonish-Rouach E, Resnitzky D, Lotem J, Sachs L, Kimchi A, Oren M. Wild-type p53 induces apoptosis of myeloid leukaemic cells that is inhibited by interleukin-6. Nature 1991; 352:345-347.

15. Shaw P, Bovey R, Tardy S, Sahli R, Sordat B, Costa J. Induction of apoptosis by wild-type p53 in a human colon tumor-derived cell line. Proc Natl Acad Sci 1992; 89:4495-4499.

16. Clarke AR, Gledhill S, Hooper ML, Bird CC, Wyllie AH. p53 dependence of early apoptotic and proliferative responses within the mouse intestinal epithelium following gamma-irradiation. Oncogene 1994; 9:1767-1773.

17. Miyashita T, Krajewski S, Krajewska M, Wang HG, Lin HK, Liebermann DA, Hoffman B, Reed JC. Tumor suppressor p53 is a regulator of bcl-2 and bax gene expression in vitro and in vivo. Oncogene 1994; 9:1799-1805.

18. Nurse P. Universal control mechanism regulating onset of M-phase. Nature 1990; 344:503-508.

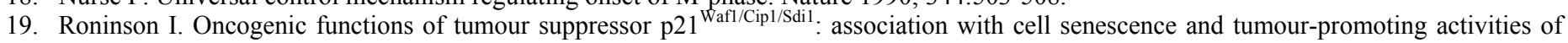
stromal fibroblasts. Cancer Letters 2002;179:1-14.

20. Adriaenssens E, Lemoine J, EI Yazidi-Belkoura I, Hondermarck H. Growth signaling in breast cancer cells: outcomes and promises of proteomics. Biochemical Pharmacology 2002; 64: 797-803.

21. Fu H, Subramanian RR, Masters SC. 14-3-3 proteins: structure, function, and regulation. Annu Rev Pharmacol Toxicol 2000; 40:617-647.

22. Chan TA, Hermeking H, Lengauer C, Kinzler KW, Vogelstein B. 14-3-3 sigma is required to prevent mitotic catastrophe after DNA damage. Nature (Lond) 1999; 401:616-620.

23. Laronga C, Yang HY, Neal C, Lee MH. Association of the cyclin-dependent kinases and 14-3-3 sigma negatively regulates cell cycle progression. JBC 2000; 275:23106-23112.

24. Urano T, Saito T, Tsukui T, Fujita M, Hosoi T, Muramatsu $\mathrm{M}$, Ouchi Y, Inoue S. Efp targets 14-3-3 sigma for proteolysis and promotes breast tumour growth. Nature 2002; 417:871875.

\section{Figures}

Figure 1. The effect of CKBM on cell proliferation. Data points represent the mean of 4 replicates. Percentage of proliferation was calculated by (Abs cells - Abs background) treated $\left(\right.$ Abs $_{\text {cells }}-$ Abs background $_{\text {control }}$ X 100

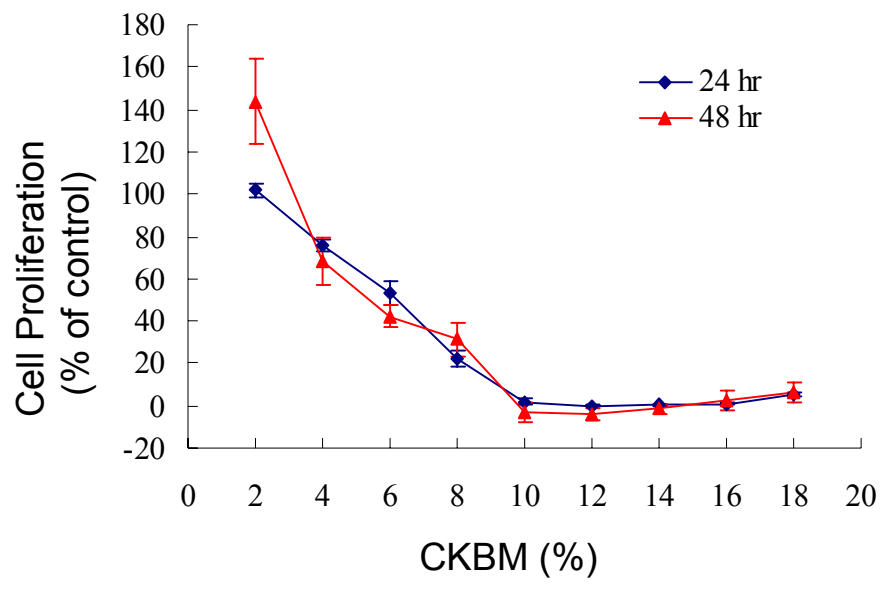


Figure 2. Morphological changes of AGS cancer cells treated for $48 \mathrm{hr}$ with the indicated CKBM concentration.

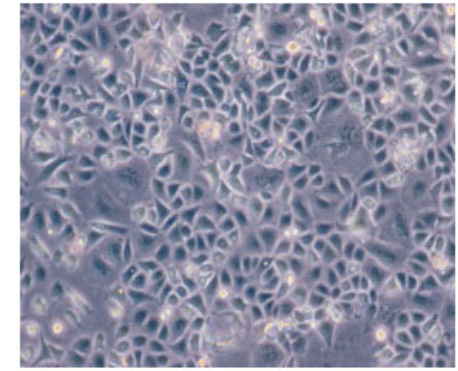

Control

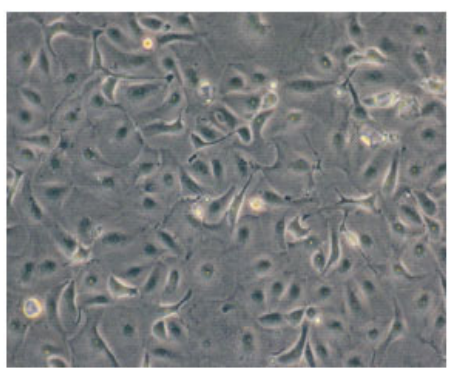

CKBM $10 \%$

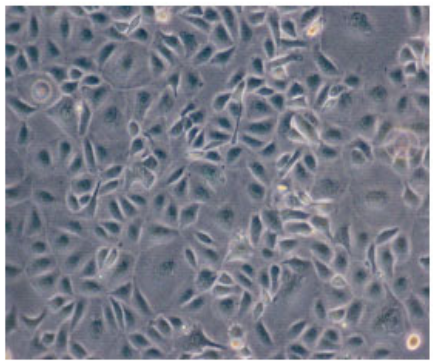

CKBM 5\%

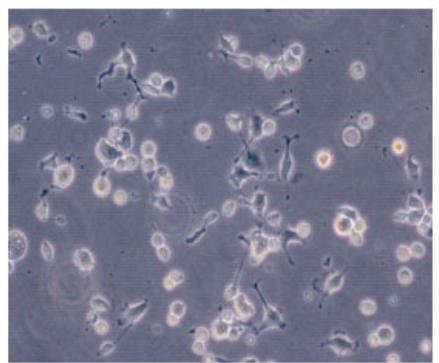

CKBM $15 \%$

Figure 3. Analysis of cell cycle progression. AGS cancer cells were untreated or treated with CKBM. Cells were harvested after 24, 48 or $72 \mathrm{hr}$ then they were fixed, stained and analyzed for DNA content. The distribution and percentage of cells in pre-phase, G1, S and $\mathrm{G} 2 / \mathrm{M}$ phase of the cell cycle are indicated.
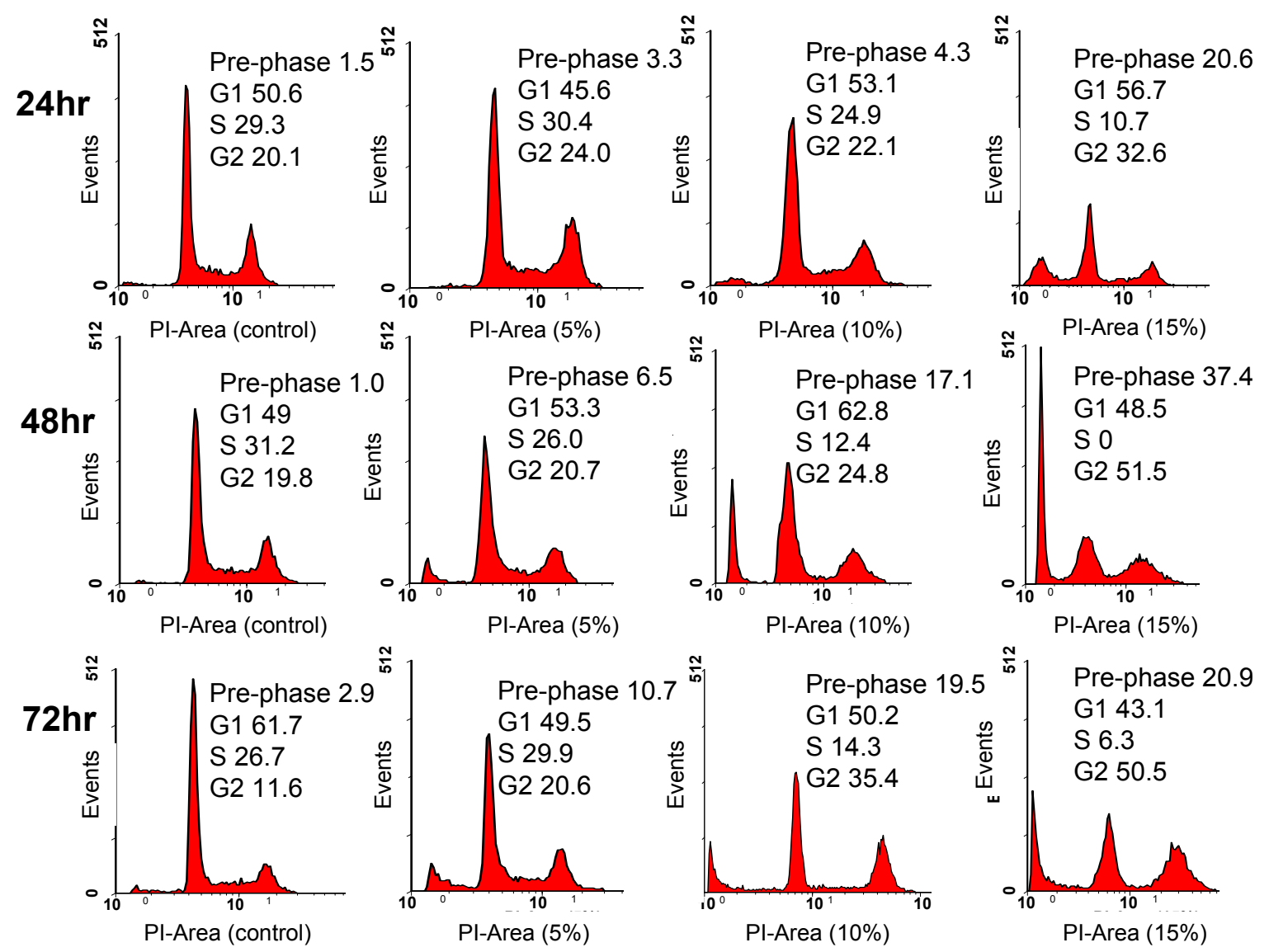
Figure 4. AGS cells stained with anti-Annexin V. The percentage of apoptotic cells is indicated.
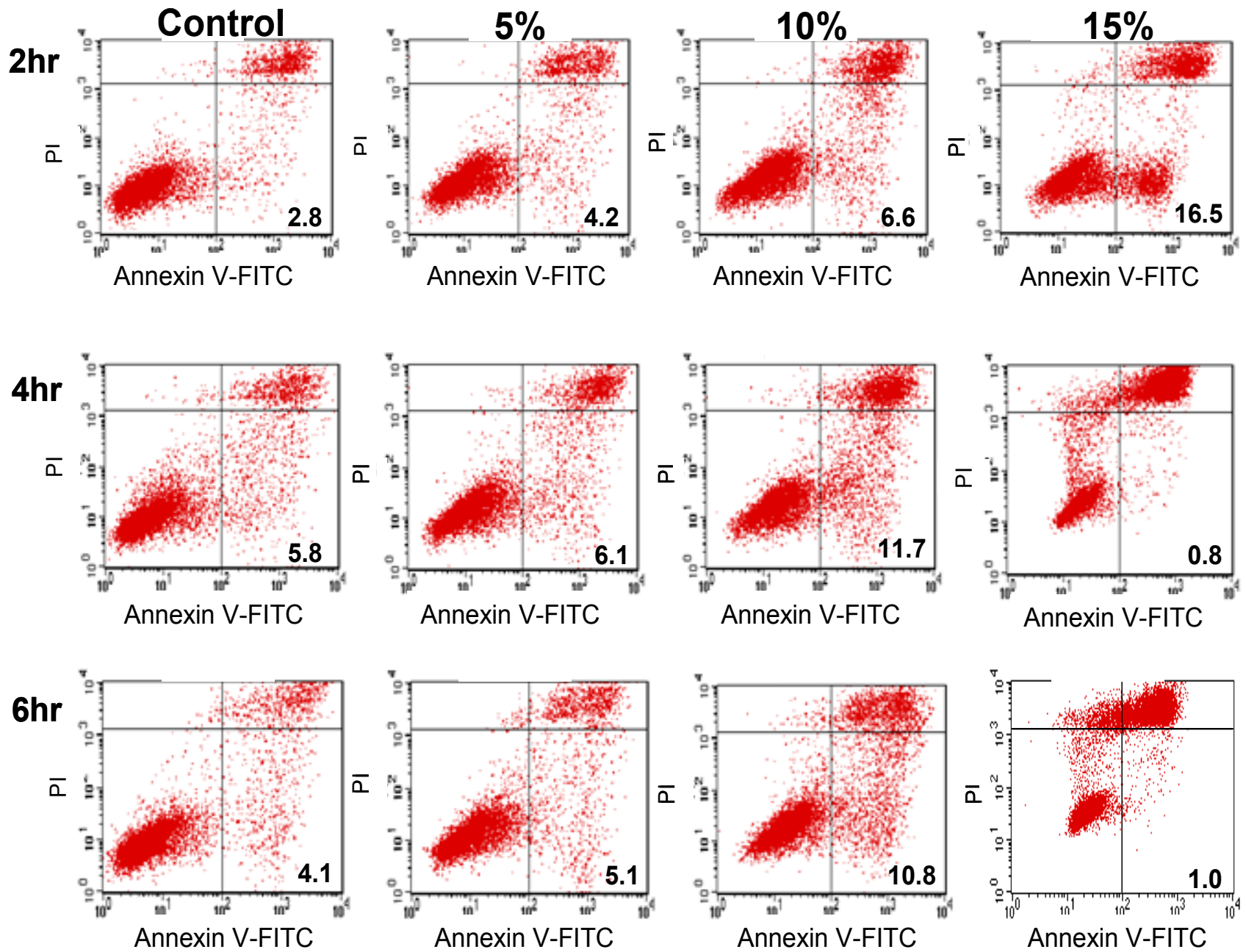

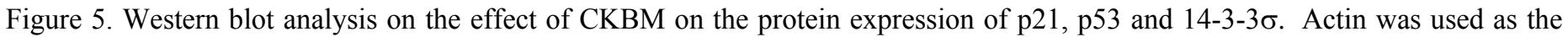
internal control.

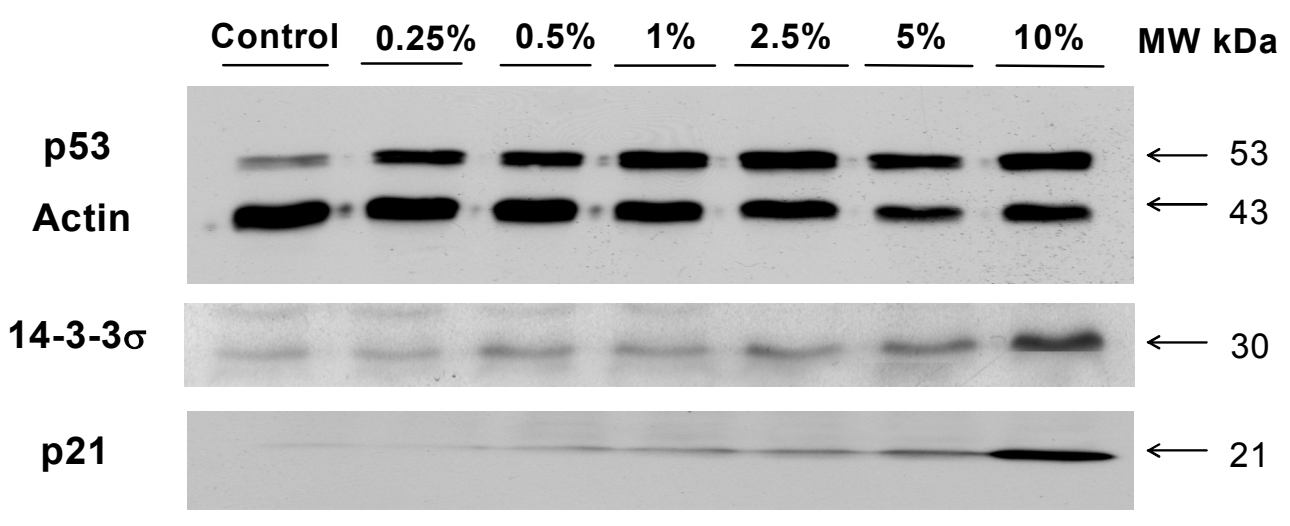

